УДК 697.94.(075)

В.Й. Лабай, Д.І. Гарасим

Національний університет «Львівська політехніка», вул. Ст. Бандери, 12, Львів, 79013, Україна

\title{
ЗАЛЕЖНІСТЬ ЕКСЕРГЕТИЧНОГО ККД СИСТЕМИ КОНДИЦІЮВАННЯ ПОВІТРЯ ОПЕРАЦІЙНИХ ЧИСТИХ КІМНАТ ВІД КОЕФІЦІЄНТА ТРАНСФОРМАЦІЇ ХОЛОДИЛЬНОї МАШИНИ
}

\begin{abstract}
У статті використана авторська інноваційна математична дослідницька модель впровадженої центральної прямотечійної системи кондиціювання повітря операційних чистих кімнат. Мета моделі - комп'ютерне оиінювання ексергетичної ефективності діючої системи кондиціювання залежно від різних факторів, щзо впливають на ії роботу, зокрема коефіцієнта трансформації ЕER ї̈ холодильної мачини. Завдяки цій моделі встановлено вплив коефіцієнта трансформації холодильної машини на ексергетичний ККД діючої системи кондиціювання за різних параметрів зовнішнього і внутрішнього повітря та різниці температур внутрішнього $i$ припливного повітря.

Ключові слова: Ексергетичний баланс - Системи кондиціювання повітря - Чисті приміщення - Ексергетична ефективність - Коефіцієнт трансформаиї̈ EER

Национальный университет «Львовская политехника», ул. Ст. Бандеры, 12, Львов, 79013, Украина

\section{ЗАВИСИМОСТЬ ЕКСЕРГЕТИЧЕСКОГО КПД СИСТЕМЫ КОНДИЦИОНИРОВАНИЯ ВОЗДУХА ОПЕРАЦИОННЫХ ЧИСТЫХ КОМНАТ ОТ КОЭФФИЦИЕНТА ТРАНСФОРМАЦИИ ХОЛОДИЛЬНОЙ МАШИНЫ}

\section{В.И. Лабай, Д.И. Гарасымм}

\begin{abstract}
В статье использована авторская инновачионная математическая исследовательская модель внедренной центральной прямоточной системы кондиционирования воздуха операционных чистых комнат. Цель модели - компьютерная оценка эксергетической эффективности действующей системы кондиционирования в зависимости от разных факторов, какие влияют на ее работу, в частности коэффичиента трансформачии EER ее холодильной машины. Благодаря этой модели определено влияние коэффициента трансформаџии ЕЕR холодильной машины на эксергетический КПД действующей системы кондиционирования при разных параметрах наружного $и$ внутреннего воздуха и разности температур внутреннего $u$ приточного воздуха.
\end{abstract}

Ключевые слова: Эксергетический баланс - Системы кондиционирования воздуха - Чистые помещения - Эксергетическая эффективность - Коэффициент трансформации ЕER

DOI: $10.15673 / 0453-8307.3 / 2015.42636$

This work is licensed under the Creative Commons Attribution International License (CC BY). http://creativecommons.org/licenses/by/4.0/

\section{I. ВСТУП}

Нині під час експлуатації енерготехнологічних систем (ЕТС), до яких належать системи кондиціювання повітря (СКП), для забезпечення проведення певної технології питання економії паливно-енергетичних ресурсів має першорядне значення. Тому зараз ставиться питання про ЕТС, в яких би вимоги технології та енергетики не тільки органічно поєднувались, але й доповнювали одне одного.

У сучасних технологіях, пов'язаних 3 перетворенням енергії, а саме у СКП, важливе місце займають обладнання і процеси, об'єктивна оцінка ступеня енергетичної досконалості яких може бути встановлена тільки на основі їх термодинамічного аналізу. Найпростішим методом термо- динамічного аналізу є енергетичний, заснований на законі збереження енергії. Він дозволяє оцінити абсолютні і відносні втрати енергії, виявити обладнання і процеси 3 найбільшими втратами. Однак цей метод прирівнює один до одного цінності всіх видів енергії, зокрема і теплової, що невірно $з$ позицій другого закону термодинаміки, оскільки будь-який вид енергії може повністю перетворюватись у теплову, зворотній же процес супроводжується неминучими втратами.

Під впливом цих вимог в останні десятиріччя був розроблений універсальний ексергетичний метод аналізу. Цей метод був обгрунтований у роботах Р.К. Клаузіуса, Дж.В. Гіббса, Ж. Гюі, А. Стодоли, Я. Шаргута та Р. Петели [6-10]. Його основна ідея полягає у введенні поряд з загальним, фундаментальним поняттям енергії, додаткового 
показника - ексергї, який дозволяє врахувати той факт, що енергія залежно від зовнішніх умов може мати різну цінність для практичного використання.

Розрахунки балансів і різних характеристик ЕTC, зокрема СКП, з врахуванням ексергії дає можливість найпростіше і наглядніше вирішувати безліч наукових i технічних задач. Вони допомагають вилучити часті помилки, які зустрічаються і пов'язані з ігноруванням якісного боку перетворень.

Ексергетичний баланс для даної ЕТС, тобто впровадженої авторами системи кондиціювання повітря операційних чистих кімнат, має такий вигляд:

$$
E_{\mathrm{BX}}=E_{\text {вих }}+\sum_{i=1}^{n} D_{i}, \text { Вт, }
$$

або

$$
\sum_{i=1}^{n} D_{i}=E_{\mathrm{вх}}-E_{\text {вих }}, \text { Вт, }
$$

де $E_{\mathrm{Bx}}-$ ексергія приводу СКП, яка витрачається на підтримання процесу, Вт; $E_{\text {вих }}-$ приріст ексергії повітря у кондиціонованих приміщеннях, Вт; $\sum_{i=1}^{n} D_{i}$ - сума ексергетичних втрат ЕТС, Вт.

Ексергетичний баланс даної ЕТС складали на основі ії принципової схеми (рисунок 1).

Вочевидь, досконалість ЕТС та ії елементів тим вища, чим вищий ексергетичний ККД, який визначали з ексергетичного балансу, а саме [6-10, $12,13,15-20]$ :

$$
\eta_{\mathrm{e}}=\frac{E_{\mathrm{Bux}}}{E_{\mathrm{BX}}} .
$$

Розрахунок ексергетичного ККД ЕТС створює умови для вирішення питання економії паливно-енергетичних ресурсів [7, 8, 11-13, 16, 18-20].

Отже, ексергетичний ККД ЕТС обраховували за формулою (3), в якій чисельник є корисним ексергетичним ефектом, а знаменник - затратами ексергії, а отже ексергетичний ККД визначали за формулою:

$$
\eta_{\mathrm{e}}=\frac{E_{\text {вих }}}{E_{\text {вих }}+\sum_{i=1}^{n} D_{i}}=\frac{E_{\text {еф }}}{E_{\text {затр }}} .
$$

Ефективність роботи будь-якої системи кондиціювання повітря (СКП) залежить від енергоефективності холодильної машини (ХМ), яка іiї обслуговує та споживає електричну енергію для зменшення теплоти припливного у приміщення повітря. А це означає, що головна мета вибору певної холодильної машини для СКП - досягти максимальної холодопродуктивності за мінімального енергоспоживання. Тому для оцінки енергоефективності холодильних машин введений коефіцієнт енергетичної ефективності EER (Energy Efficiency Rate), або коефіцієнт трансформації, який дорівнює відношенню холодопродуктивності до повної споживаної потужності за розрахункових (стандартних) умов роботи:

$$
E E R=\frac{Q_{\mathrm{x}}}{N_{\mathrm{c \Pi}}}
$$

де $Q_{\mathrm{x}}-$ холодопродуктивність ХМ, Вт; $N_{\text {сп }}-$ споживана потужність ХМ, Вт.

У даний час $E E R$ для ХМ може бути від 1,8 до 5. Для позначення енергоефективності ХМ є сім категорій, які позначаються буквами від «A» (кращої) до «G» (гіршої). ХМ категорії «A» $E E R \geq 3,2$, а категорії «G» $E E R<2,2$.

Тому метою даної роботи було дослідити вплив коефіцієнта трансформації EER XM на ексергетичний ККД $\eta_{\mathrm{e}}$ впровадженої центральної прямотечійної СКП операційних чистих кімнат.

\section{I. ОПИСАННЯ ОБ'СКТУ АНАЛІЗУ ТА ІННОВАЦІЙНОЇ ДОСЛІДНИЦЬКОЇ МОДЕЛІ}

Метою кондиціювання повітря є підтримання у деякому обмеженому просторі (у даному випадку у чистих операційних кімнатах) певних параметрів повітря. Звичайно регулюванню підлягає температура $t_{\mathrm{B}}$ і відносна вологість $\varphi_{\mathrm{B}}$ повітря, а у чистих операційних кімнатах це ще й концентрація частинок $x_{\text {в }}$ у повітрі [1-5].

Розглянемо впроваджену авторами центральну прямотечійну СКП для операційних чистих кімнат, схематично зображену на рисунку 1 . Робота такої системи залежить від домінуючих у зовнішньому середовищі умов, тобто від температури і вологовмісту зовнішнього повітря. Отже, у теплий період року (ТПР) зовнішнє повітря через клапан 11 забирається центральним кондиціонером, очищається у фільтрі 10, далі проходить через повітронагрівник 9, охолоджується та осушується за політропою у повітроохолоднику 8, сепарується у краплевловнику 7, а відтак вентиляторним агрегатом 6 подається через фільтр кондиціонера 5 і фільтри 3 на вході у чисті операційні кімнати. Видаляється відпрацьоване повітря 3 операційних чистих приміщень 3 верхньої і нижньої зон витяжною установкою через ii клапан 17 витяжним вентилятором 18.

Наведемо роботу даної СКП у ТПР, коли температура $t_{\mathrm{B}}<t_{3}$. На рисунку 2 приведена у системі координат $I, d$ послідовність зміни параметрів повітря, яке проходить через різне обладнання впровадженої центральної прямотечійної системи кондиціювання повітря для операційних чистих кімнат у ТПР за різних параметрів зовнішнього повітря. У дослідженнях прийнято масову продуктивність СКП, пораховану за необхідною кратністю повітрообміну, $G=4300$ кг/год, параметри зовнішнього повітря змінювались у межах: температура $t_{3}=30-40^{\circ} \mathrm{C}$; відносна вологість $\varphi_{3}=44-36 \%$ (відповідно, питома ентальпія 
вологовміст $d_{3}=11,7-16,8$ г/кг; $I_{3}=60,1-83,4$ кДж/кг), барометричний тиск $p_{3}=1010$ гПа; параметри внутрішнього повітря відповідно $-t_{\text {в }}=25$ $29^{\circ} \mathrm{C} ; \varphi_{\mathrm{B}}=54-64 \%$ (відповідно, $d_{\mathrm{B}}=10,8-16,3$ г/кг; $I_{\text {в }}=52,6-70,8$ кДж/кг); різниця температур між внутрішнім і припливним повітрям залежно від теплонадлишків у чистому приміщенні, а також температури зовнішнього повітря $\Delta t_{\Pi}=t_{\mathrm{B}}-t_{\Pi}=9,0-4,0^{\circ} \mathrm{C} ;$ кутовий коефіцієнт процесу асиміляції тепло- і вологонадлишків у чистих приміщеннях припливним повітрям 3 кондиціонера $\varepsilon=27058-9711$ кДж/кг; початкова температура холодоносія (40\% розчину пропіленгліколю) для повітроохолодника: $t_{\mathrm{B}_{п}}=9,5-15,5^{\circ} \mathrm{C}$.

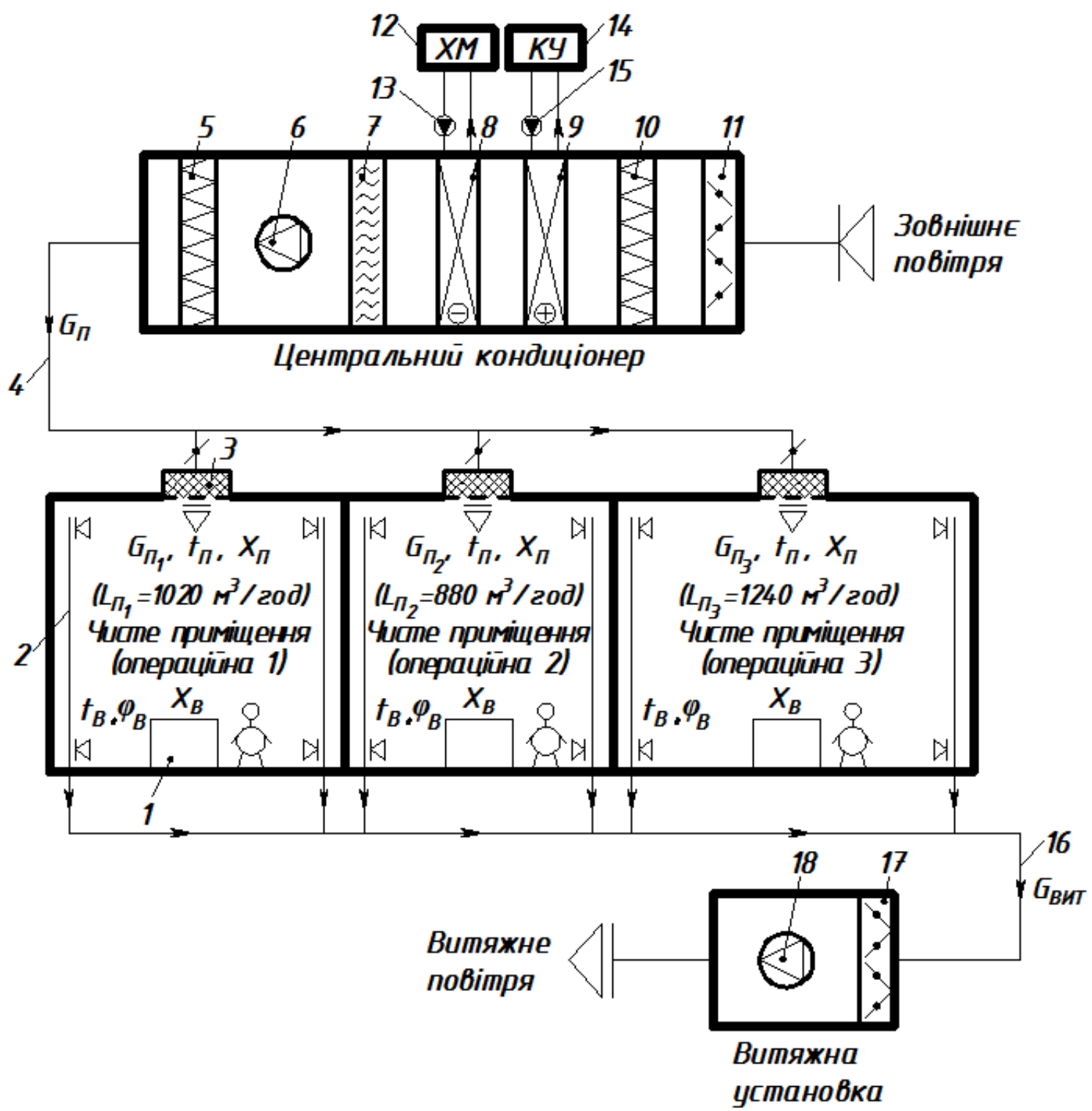

Рисунок 1 - Принципова схема впровадженої цчентральної прямотечійної СКП для операційних чистих кімнат: 1 - технологічне обладнання; 2 - витяжні канали у приміщеннях;

3 - фільтри припливного повітря у приміщення; 4 - припливний повітропровід;

5 - фільтр припливного повітря у кондиціонері; 6 - вентиляторний агрегат кондиціонера;

7 - краплевловник кондиціонера; 8 - повітроохолодник кондиціонера;

9 - повітронагрівник кондиціонера; 10 - фільтр зовнішнього повітря у кондиціонері;

11 - клапан зовнішнього повітря у кондиціонері; 12 - холодильна машина ХМ;

13 - насос холодної води ХМ; 14 - котельна установка КУ; 15 - насос гарячої води;

16 - витяжний повітропровід; 17 - клапан витяжного повітря;

18 - вентиляторний агрегат витяжної установки 
Послідовність змін, які відбуваються 3 вологим повітрям, що проходить через різне обладнання впровадженої системи кондиціювання повітря, наведені на рисунку 2. Побудова на $I-d-$ діаграмі виконана згідно з [11]. Параметри повітря у характерних точках процесу (рисунок 2) встановлювались за значеннями відповідних параметрів для зовнішнього повітря та підраховувались за відомими аналітичними залежностями для вологого повітря.

Авторами була створена інноваційна дослідницька математична модель впровадженої системи кондиціювання повітря для комп'ютерного оцінювання ii ексергетичної ефективності залежно від коефіцієнта трансформації $E E R$ холодильної машини центрального кондиціонера за різних параметрів зовнішнього і внутрішнього повітря та різниці температур між внутрішнім і припливним повітрям. Завдяки цій моделі отримано результати досліджень, які зведені у таблицю 1.

Ексергетичний ККД, який характеризує ефективність роботи впровадженої центральної прямотечійної системи кондиціювання операційних чистих кімнат у ТПР, визначали за формулою (4), у якій $E_{\text {вих }}=E_{\Pi}-E_{\mathrm{B}}-$ зменшення ексергії кондиціонованого повітря у у чистих кімнатах кардіологічних операційних (корисно використана ексергія), Вт; $E_{\Pi}$ i $E_{\mathrm{B}}-$ відповідно, ексергія припливного i внутрішнього повітря у чистих кімнатах, Вт; $D_{\Pi_{0}}=E_{\Pi_{1}}-E_{3}-$ втрата ексергії повітря у повітроохолоднику кондиціонера, Вт; $E_{\Pi_{1}}$ і $E_{3}-$ відповідно, ексергія оброблюваного повітря на виході та вході (зовнішнього повітря) у повітроохолодник кондиціонера, Вт; $D_{\Pi_{1} \Pi}=E_{\Pi_{1}}-E_{\Pi}-$ втрата ексергії повітря під час його транспортування у припливних повітропроводах i вентиляторі СКП, Вт; $E_{\Pi_{1}}$ i $E_{\Pi}-$ відповідно, ексергія повітря на вході у припливний вентилятор кондиціонера та виході 3 припливних повітропроводів у чисті кімнати, $\mathrm{BT}$; $D_{\text {вит }}=E_{\mathrm{B}}-E_{3}-$ втрати ексергї 3 витяжним кондиціонованим повітрям 3 чистих кімнат, Вт; $D_{\text {пр.вент }}$ - втрата ексергії 3 припливним вентилятором кондиціонера, Вт; $D_{\text {вит.вент }}-$ втрата ексергії з вентилятором витяжної установки, Вт; $D_{\text {Хм }}$ - втрата ексергії з холодильною машиною центрального кондиціонера, Вт. Отже, загальні втрати ексергії у діючій СКП визначали так:

$$
\begin{aligned}
& \sum_{i=1}^{n} D_{i}=D_{\text {ПО }}+D_{\Pi_{1} \Pi}+D_{\text {вит }}+ \\
& +D_{\text {пр.вент }}+D_{\text {вит.вент }}+D_{\text {ХМ }}, \text { Вт. }
\end{aligned}
$$

Як конкретно визначали величини, що входять у формулу (4) подано у [19, 20].

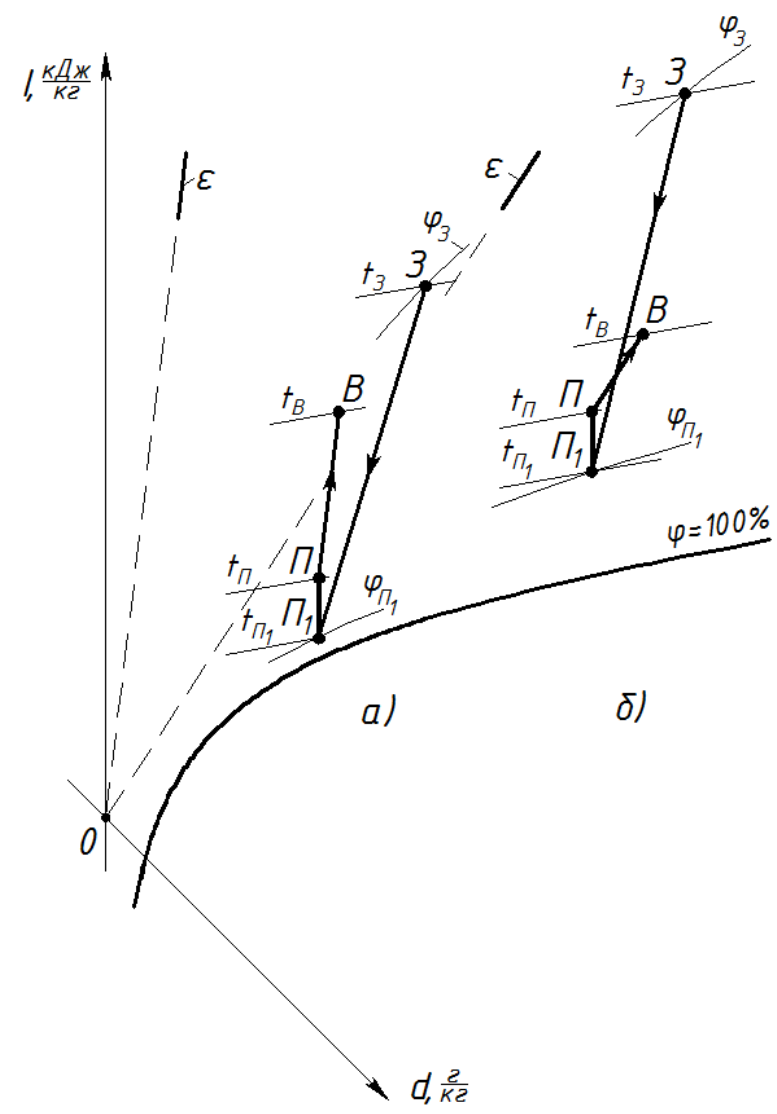

Рисунок 2 - Зображення процесів зміни стану вологого повітря у діючій прямотечійній СКП у ТПР на I-d-діаграмі

a) для умов проведення досліджень $-t_{3}=30$;

$32^{\circ} \mathrm{C} ; t_{\mathrm{B}}=25 ; 26^{\circ} \mathrm{C} ; \Delta t_{\Pi}=9 ; 7^{\circ} \mathrm{C} ;$

б) для умов проведення досліджень $-t_{3}=35$;

$38 ; 40^{\circ} \mathrm{C} ; t_{\mathrm{B}}=27 ; 28 ; 29^{\circ} \mathrm{C} ; \Delta t_{\Pi}=6 ; 5 ; 4^{\circ} \mathrm{C}$ :

$3 \Pi_{1}-$ процес політропного оброблення

(охолодження та осушування) повітря $G_{3}=G_{\Pi}$ у повітроохолоднику;

$\boldsymbol{\Pi}_{\boldsymbol{1}} \boldsymbol{\Pi}$ - процес підігрівання повітря $G_{\Pi}$ на $1^{\circ} \mathrm{C}$ у вентиляторі та припливному повітропроводi;

ПВ - процес асиміляиії тепло- $i$ вологонадлишків у чистих приміщеннях припливним повітрям $G_{\Pi}$ з кондиџіонера

\section{III. РЕЗУЛЬТАТИ ДОСЛІДНИЦЬКОЇ РОБОТИ}

На основі досліджень, проведених нами на інноваційній математичній моделі для вказаної СКП, отримано залежність ексергетичного ККД $\eta_{\mathrm{e}}$ від коефіцієнта трансформації EER iї холодильної машини за різних параметрів зовнішнього $\left(t_{3}, \varphi_{3}\right)$ і внутрішнього $\left(t_{\mathrm{B}}, \varphi_{\mathrm{B}}\right)$ повітря та різниці температур $\Delta t_{\text {п }}$ між внутрішнім і припливним повітрям, які подані на рисунку 3 і у таблиці 1.

Аналізуючи отримані дані досліджень на рисунку 3 і у таблиці 1, можна дійти таких висновків. 
Загальне зростання коефіцієнта трансформації $E E R$ від 2,6 до 4,0, тобто в 1,54 рази, призводить до зростання значення ексергетичного ККД $\eta_{\mathrm{e}}$ за різних умов проведення досліджень від 1,29 до 1,30 рази або на 29-30\%. Варто також зауважити (рисунок 3 i таблиця 1), що за найбільшої різниці температур між внутрішнім і припливним повітрям $\Delta t_{\Pi}=9,0^{\circ} \mathrm{C} \epsilon$ найвищі значення ексергетичного ККД $\eta_{\mathrm{e}}$. А це значить, що за певної температури зовнішнього повітря $t_{3}$ різницю температур між внутрішнім $t_{\text {в }}$ i припливним $t_{\Pi}$ повітрям $\Delta t_{\Pi}$ за можливості потрібно приймати максимальною. Тому вибрану систему кондиціювання повітря бажано використовувати за вищого коефіцієнта трансформації $E E R$ іiі холодильної машини та вищої різниці температур між внутрішнім і припливним повітрям за різних температур зовнішнього повітря, що дасть можливість отримати найвищий ексергетичний ККД $\eta_{\mathrm{e}}$, а значить отримати економічно найвигідніший варіант використання впровадженої системи кондиціювання повітря.

Залежності, наведені на рисунку 3 і у таблиці 1 , отримані нами у вигляді аналітичної формули для різниці температур між зовнішнім i внутрішнім повітрям $\Delta t_{\Pi}=4,0-9,0^{\circ} \mathrm{C}$ та коефіцієнта трансформації $E E R=2,6-4,0$ :

$$
\begin{gathered}
\eta_{\mathrm{e}}=0,1456 \cdot E E R+0,0328 \cdot \Delta t_{\Pi}+ \\
+0,0195 \cdot E E R \cdot \Delta t_{\Pi}+0,3206,
\end{gathered}
$$

Максимальна похибка розрахунків за формулою (7) становить 6,0\%.

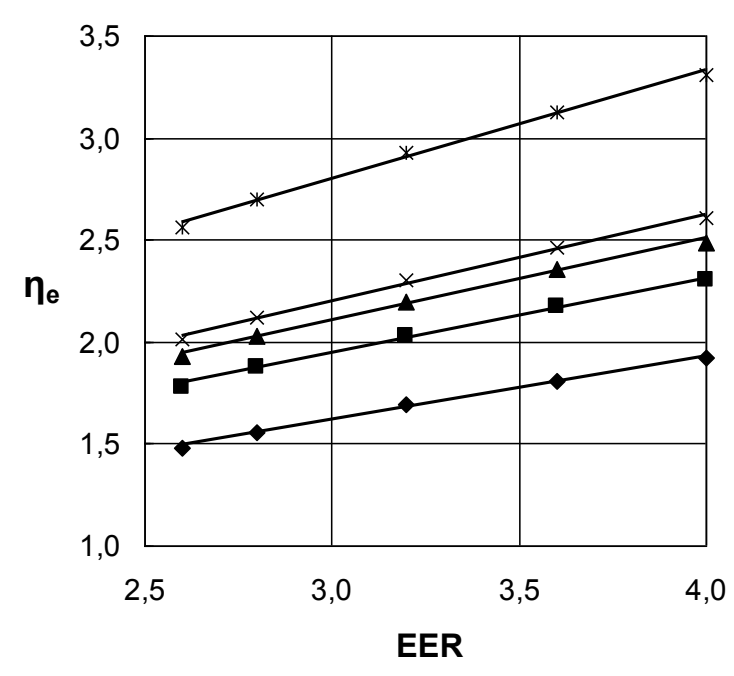

Рисунок 3 - Залежність ексергетичного ККД $\eta_{\mathrm{e}}$ впровадженої иентральної прямотечійної

СКП операційних чистих кімнат від коефіиієнта трансформаиії ЕER XM i умов проведення досліджень:

1 ряд $-t_{3}=40^{\circ} \mathrm{C} ; \varphi_{3}=36 \% ; t_{\mathrm{B}}=29^{\circ} \mathrm{C}$;

$\varphi_{\mathrm{B}}=64 \% ; \Delta t_{\Pi}=4,0^{\circ} \mathrm{C} ; \varphi_{\Pi}=79 \%$;

2 ряд п-38; 38; 28; 64; 5,0; 84\%;

3 ряд А - 35; 40; 27; 60; 6,0;84\%;

4 ряд $х-32 ; 42 ; 26 ; 55 ; 7,0 ; 82 \%$;

5 ряд ж-30; 44; 25; 54; 9,0; $92 \%$

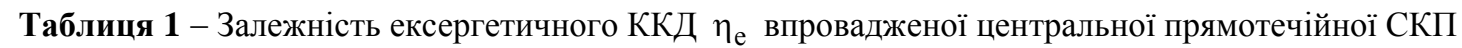

\begin{tabular}{|c|c|c|c|c|c|}
\hline \multirow{3}{*}{$E E R$} & \multicolumn{5}{|c|}{ Умови проведення досліджень } \\
\hline & $\begin{array}{l}t_{3}=30^{\circ} \mathrm{C} ; \\
\varphi_{3}=44 \% ; \\
t_{\mathrm{B}}=25^{\circ} \mathrm{C} ; \\
\varphi_{\mathrm{B}}=54 \% ; \\
\Delta t_{\Pi}=9,0^{\circ} \mathrm{C} ; \\
\varphi_{\Pi}=92 \%\end{array}$ & $\begin{array}{l}t_{3}=\mathbf{3 2}{ }^{\circ} \mathrm{C} ; \\
\varphi_{3}=42 \% ; \\
t_{\mathrm{B}}=26^{\circ} \mathrm{C} ; \\
\varphi_{\mathrm{B}}=55 \% ; \\
\Delta t_{\Pi}=7,0^{\circ} \mathrm{C} ; \\
\varphi_{\Pi}=82 \%\end{array}$ & $\begin{array}{l}t_{3}=35^{\circ} \mathrm{C} ; \\
\varphi_{3}=40 \% ; \\
t_{\mathrm{B}}=27^{\circ} \mathrm{C} ; \\
\varphi_{\mathrm{B}}=60 \% ; \\
\Delta t_{\Pi}=6,0^{\circ} \mathrm{C} ; \\
\varphi_{\Pi}=84 \%\end{array}$ & $\begin{array}{l}t_{3}=38^{\circ} \mathrm{C} ; \\
\varphi_{3}=38 \% ; \\
t_{\mathrm{B}}=28^{\circ} \mathrm{C} ; \\
\varphi_{\mathrm{B}}=64 \% ; \\
\Delta t_{\Pi}=5,0^{\circ} \mathrm{C} ; \\
\varphi_{\Pi}=84 \%\end{array}$ & $\begin{array}{l}t_{3}=40^{\circ} \mathrm{C} ; \\
\varphi_{3}=36 \% ; \\
t_{\mathrm{B}}=29^{\circ} \mathrm{C} ; \\
\varphi_{\mathrm{B}}=64 \% ; \\
\Delta t_{\Pi}=4,0^{\circ} \mathrm{C} ; \\
\varphi_{\Pi}=79 \%\end{array}$ \\
\hline & $\eta_{\mathrm{e}}, \%$ & $\eta_{\mathrm{e}}, \%$ & $\eta_{\mathrm{e}}, \%$ & $\eta_{\mathrm{e}}, \%$ & $\eta_{\mathrm{e}}, \%$ \\
\hline 2,6 & 2,56 & 2,01 & 1,93 & 1,78 & 1,48 \\
\hline 2,8 & 2,70 & 2,12 & 2,03 & 1,88 & 1,56 \\
\hline 3,2 & 2,93 & 2,30 & 2,20 & 2,03 & 1,69 \\
\hline 3,6 & 3,13 & 2,46 & 2,36 & 2,17 & 1,81 \\
\hline 4,0 & 3,31 & 2,61 & 2,49 & 2,30 & 1,92 \\
\hline
\end{tabular}
операційних чистих кімнат від коефіцієнта трансформації $E E R$ холодильної машини кондиціонера 
Значить ексергетичний аналіз впровадженої центральної прямотечійної системи кондиціювання повітря операційних чистих кімнат виконаний на створеній авторами інноваційній математичній дослідницькій моделі дав можливість грунтовно оцінити залежність ексергетичного ККД $\eta_{\mathrm{e}}$ цієї системи від коефіцієнта трансформації $E E R$ холодильної машини кондиціонера за різних параметрів зовнішнього $\left(t_{3}, \varphi_{3}\right)$ і внутрішнього $\left(t_{\mathrm{B}}, \varphi_{\mathrm{B}}\right)$ повітря та різниці температур $\Delta t_{\text {п }}$ між внутрішнім і припливним повітрям.

\section{IV. ВИСНОВКИ}

Використана створена авторами інноваційна математична дослідницька модель впровадженої центральної прямотечійної системи кондиціювання повітря операційних чистих кімнат, що дає можливість комп'ютерного оцінювання її енергоефективності на основі ексергетичного ККД $\eta_{\mathrm{e}}$ залежно від різних факторів, що впливають на iii роботу, зокрема коефіцієнта трансформації $E E R$ iii холодильної машини $[19,20]$. Наведено залежність ексергетичного ККД $\eta_{\mathrm{e}}$ впровадженої центральної прямотечійної системи кондиціювання повітря операційних чистих кімнат від коефіцієнта трансформації $E E R$ холодильної машини кондиціонера за різних параметрів зовнішнього $\left(t_{3}, \varphi_{3}\right)$ і внутрішнього $\left(t_{\mathrm{B}}, \varphi_{\mathrm{B}}\right)$ повітря та різниці температур $\Delta t_{\text {п }}$ між внутрішнім і припливним повітрям. Показано, що вибрану систему кондиціювання повітря бажано використовувати за вищого коефіцієнта трансформації $E E R$ холодильної машини кондиціонера та вищої різниці температур між внутрішнім і припливним повітрям $\Delta t_{\Pi}$ за різних температур зовнішнього повітря $t_{3}$, що дасть можливість отримати найвищий ексергетичний ККД $\eta_{\mathrm{e}}$, а значить отримати економічно найвигідніший варіант використання впровадженої системи кондиціювання повітря.

\section{ЛІТЕРАТУРА}

1. Федотов А.Е. Чистые помещения. Второе изд., перераб. и доп. - М.: АСИНКОМ, 2003. - 576 с.

2. Хаякава И. Чистые помещения. Пер. с японск. - М.: Мир, 1990. - 456 с.

3. Уайт В. Технология чистых помещений. Основы проектирования, испытаний и эксплуатации. - М.: Клинрум, 2002. - 304 с.

4. Уайт В. Проектирование чистых помещений. Пер. с англ. - М.: Клинрум, 2004. - 360 с.

5. ГОСТ ИСО 14644-1. Чистые помещения и связанные с ними контролируемые среды. Часть 1. Классификация чистоты воздуха.

6. Соколов Е.Я. Энергетические основы трансформации тепла и процессов охлаждения: учеб. пособие для вузов.- 2-е изд., перераб. / Е.Я.
Соколов, В.М. Бродянский. - М.: Энергоиздат, 1981. - $320 \mathrm{c}$.

7. Шаргут Я. Эксергия / Я. Шаргут, Р. Петела. М.: Энергия, 1968. - 280 с.

8. Эксергетические расчеты технических систем: справ. пособие / [В.М. Бродянский, Г.П. Верхивкер, Я.Я. Карчев и др.]; под ред. А.А. Долинского, В.М. Бродянского; Ин-т технической теплофизики АН УССР. - Киев: Наук. думка, 1991. $-360 \mathrm{c}$.

9. Бродянский В.М. Эксергетический метод термодинамического анализа / В.М. Бродянский. М.: Энергия, 1973. - 296 с.

10. Бэр Г.Д. Техническая термодинамика / Г.Д. Бэр. - М.: Мир, 1977. - 518 с.

11. Богословский В.Н. Кондиционирование воздуха и холодоснабжение: Учебник для вузов / В.Н. Богословский, О.Я. Кокорин, Л.В. Петров. Стройиздат, 1985. - 367 с.

12. Прохоров В.И. Метод вычисления эксергии потока влажного воздуха / В.И. Прохоров, С.М. Шилклопер // Холодильная техника. - 1981, № 9. C. $37-41$.

13. Шилклопер С.М. Эксергетический анализ систем обеспечения микроклимата и энергоснабжения / С.М. Шилклопер, С.И. Жадин // Строительство и архитектура. Сер. 9. - 1982, вып. 4. - C. 18-27.

14. СНиП 2.04.05-86. Отопление, вентиляция и кондиционирование. - М.: ЦИТП Госстроя СССР, 1987. $-64 \mathrm{c}$

15.Янтовский Е.И. Потоки энергии и эксергии / Е.И. Янтовский. - М.: Наука, 1988. - 144 с.

16. Bes T. Egzergia w procesach ogrzewania, klimatyzacji i suszenia / T. Bes // Energetyka Przemysłowa. - 1962. 10, № 11. - S. 388-392.

17. Labaj Włodzimierz. Efektywność egzergetyczna autonomicznych klimatyzatorów miejscowych / Włodzimierz Łabaj, Oksana Omelczuk // XIV Konferencja ciepłowników „Perspektywy rozwoju ciepłownictwa". Materiały konferencyjne. - Solina: Politechnika Rzeszowska, 26-28 września 2002 r. - S. 137-144.

18. Лабай Володимир. Ексергетична ефективність центральних кондиціонерів / Володимир Лабай, Тарас Іванух // V Konferencja naukowa RzeszowskoLwowsko-Koszycka „Aktualne problemy budownictwa i inżynierii środowiska”. Zeszyty naukowe Politechniki Rzeszowskiej «Budownictwo i inżynieria środowiska». - Z. 32, część 2: Inżynieria Środowiska. - Rzeszów: Politechnika Rzeszowska, 25-26 września 2000 r. - S. 229-235.

19. Лабай В.Й. Дослідження ексергетичної ефективності систем кондиціювання повітря чистих приміщень / В.Й. Лабай, Д.І. Гарасим // Науковотехнічний журнал «Холодильна техніка і технологія», № 4 (150). - Одеса: ОНАХТ, 2014. C. $47-53$.

20. Labay V. Innovation model for energy effective investigations of air conditioning systems for cleanrooms / V. Labay, D. Harasym // ECONTECHMOD - Lublin-Rzeszow: 2014 - Vol. 3, № 1. - P. 47-52. 
V.Y. Labay, D.I. Harasym

Lviv Polytechnic National University, 12 St. Bandery str., Lviv, 79013, Ukraine

\section{THE DEPENDENCE OF THE EXERGETIC OUTPUT-INPUT RATIO OF AIR CONDITIONING SYSTEM FOR OPERATING CLEANROOMS ON COEFFICIENT OF TRANSFORMATION OF REFRIGERATION MACHINE}

Exergetic method is a universal way of thermodynamic research of various processes of energy transformation in energy technological systems, to which air conditioning system for cleanroom belongs. Implementation of exergetic analysis for energy technological system makes it possible to determine the influence of various elements of its system on its work and because of this to increase the effectiveness of work of energy technological system in general. Effectiveness of work of any air conditioning system depends on energy effectiveness of refrigeration machine, which serves it and consumes electricity for reducing the heat of supply air which enters the room. And it means that the main purpose of selection of certain refrigeration machine for air conditioning system is to reach the maximum cooling capacity with minimum energy consumption. Innovation mathematical research model of the implemented central straight flow air conditioning system for operating cleanrooms was used in this article. The aim of the model is to make computer estimation of exergy efficiency of existing air conditioning system depending on different factors, which have influence on its work, in particular the coefficient of transformation EER of its refrigeration machine. The dependence of the exergetic output-input ratio $\eta_{\mathrm{e}}$ of implemented air conditioning system for operating cleanrooms on coefficient of transformation EER of its refrigeration machine by different parameters of outdoor and indoor air and the temperature difference between the indoor and supply air were presented. It is shown, that the implemented air conditioning system should be preferably used by higher coefficient of transformation EER of its refrigeration machine and higher difference between temperatures of indoor and supply air by various temperatures of outdoor air, that will give the opportunity to gain the highest exergetic output-input ratio $\eta_{\mathrm{e}}$, which means to gain the most advantageous economical variant of exploitation of implemented air conditioning system.

Keywords: Exergetic balance; Air conditioning systems; Cleanrooms; Exergetic efficiency; Coefficient of transformation EER

\section{REFERENCES}

1. Fedotov A.E. 2003. Chistye pomeshcheniia. Vtoroe izd., pererab. i dop. - Moskva: ASINKOM, 2003. - 576 (in Russian).

2. Hayakava I. 1990. Chistye pomeshcheniia. Per. s iaponsk. - Moskva: Mir. - 456 (in Russian).

3. Whyte W. 2002. Tekhnologiia chistykh pomeshchenii. Osnovy proektirovaniia, ispytanii i ekspluatatsii. - Moskva: Klinrum. - 304 (in Russian).

4. Whyte W. 2004. Proektirovanie chistykh pomeshchenii. Per. s angl. - Moskva: Klinrum. - 360 (in Russian).

5. GOST ISO 14644-1. Chistye pomeshcheniia i sviazannye s nimi kontroliruemye sredy. Chast' 1. Klassifikatsiia chistoty vozdukha (in Russian).

6. Sokolov E.Ia. 1981. Energeticheskie osnovy transformatsii tepla i protsessov okhlazhde-niia: ucheb. posobie dlia vuzov. - 2-e izd., pererab. / E.Ia. Sokolov, V.M. Brodianskii. - Moskva: Energoizdat. 320 (in Russian).

7. Shargut Ia. 1968. Eksergiia / Ia. Shargut, R. Petela. - Moskva: Energiia. - 280 (in Russian).

8. Eksergeticheskie raschety tekhnicheskikh sistem. 1991: sprav. posobie / [V.M. Brodianskii, G.P. Verhivker, Ia.Ia. Karchev i dr.]; pod red. A.A. Dolinskogo, V.M. Brodianskogo; In-t tekhnicheskoi teplofiziki AN USSR. - Kiev: Nauk. dumka. - 360.
9. Brodianskii V.M. 1973. Eksergeticheskii metod termodinamicheskogo analiza / V.M. Brodianskii. Moskva: Energiia. - 296 (in Russian).

10. Ber G.D. 1977. Tekhnicheskaia termodinamika / G.D. Ber. - Moskva: Mir. - 518 (in Russian).

11. Bogoslovskii V.N. 1985. Konditsionirovanie vozdukha i kholodosnabzhenie: Uchebnik dlia vuzov / V.N. Bogoslovskii, O.Ia. Kokorin, L.V. Petrov. Stroiizdat. - 367 (in Russian).

12. Prokhorov V.I. 1981. Metod vychisleniia eksergii potoka vlazhnogo vozdukha / V.I. Prokhorov, S.M. Shilkloper // Kholodil'naia tekhnika. - № 9. - 37-41 (in Russian).

13. Shilkloper S.M. 1982. Eksergeticheskii analiz sistem obespecheniia mikroklimata i energosnabzheniia / S.M. Shilkloper, S.I. Zhadin // Stroitel'stvo i arkhitektura. Ser. 9. - Vyp. 4. - 18-27 (in Russian).

14.SNiP 2.04.05-86. 1987. Otoplenie, ventiliatsiia i konditsionirovanie. - Moskva: TsITP Gosstroia SSSR. -64 (in Russian).

15. Iantovskii E.I. 1988. Potoki energii i eksergii / E.I. Iantovskii. - Moskva: Nauka. - 144 (in Russian).

16. Bes T. 1962. Egzergia $w$ procesach ogrzewania, klimatyzacji i suszenia / T. Bes // Energetyka Przemysłowa. - 10, № 11. - 388-392 (in Polish).

17. Labaj Włodzimierz. 2002. Efektywność egzergetyczna autonomicznych klimatyzatorów miejscowych / Włodzimierz Łabaj, Oksana Omelczuk // XIV Konferencja ciepłowników „Perspektywy 
rozwoju ciepłownictwa”. Materiały konferencyjne. Solina: Politechnika Rzeszowska, 26-28 września. 137-144 (in Ukrainian).

18. Labai Volodymyr. 2000. Eksergetychna efektyvnist' tsentral'nykh kondytsioneriv / Volodymyr Labai, Taras Ivanukh // V Konferencja naukowa Rzeszowsko-Lwowsko-Koszycka „Aktualne problemy budownictwa i inżynierii środowiska". Zeszyty naukowe Politechniki Rzeszowskiej «Budownictwo i inżynieria środowiska». - Z. 32, część 2: Inżynieria Środowiska. - Rzeszów: Politechnika Rzeszowska, 25-26 września. - 229-235 (in Ukrainian).
19. Labay V.Y. 2014. Doslidzhennia eksergetychnoi efektyvnosti system kondyciiuvannia povitria chystykh prymishchenn' / V.Y. Labay, D.I. Harasym // Naukovo-tekhnichnyi zhurnal «Kholodyl'na tekhnika i tekhnologiia», № 4 (150). - Odesa: ONAKHT. - 47-53 (in Ukrainian).

20. Labay V. 2014. Innovation model for energy effective investigations of air conditioning systems for cleanrooms / V. Labay, D. Harasym // ECONTECHMOD - Lublin-Rzeszow: 2014 - Vol. 3, № 1. - 47-52 (in English).

Отримана в редакції 15.04.2015, прийнята до друку 23.04.2015 